\title{
THE ANALYSIS OF THE MONETARY POLICY DYNAMICS IN ROMANIA USING A STRUCTURAL VECTOR AUTOREGRESSIVE MODEL
}

\author{
Prof. Cristi SPULBĂR, PhD \\ Mihai NIȚOI, PhD student \\ Assoc. Prof. Lavinia NEȚOIU, PhD \\ University of Craiova
}

\section{Introduction}

The efficient functioning of the enlarged future euro zone still needs some answers to a set of essential questions. One of these questions is related to the pertinence of the inflation target of $2 \%$ established by the European Central Bank (ECB). Indeed, despite of a considerable deceleration of the prices growth rhythm in the Central and Eastern Europe countries after the difficult period of transition, an inflation growth is possible after the euro adoption. According to Benassy-Quere and Lahreche-Revil (2001), this phenomenon could lead to the medium inflation growth of the euro zone of $0.25 \%$ and of $0.75 \%$. In order to accomplish its mandate, ECB will be constraint to implement a restrictive monetary policy, whose deflationary incidents could compromise the real convergence process of the new members of the euro zone.

In these conditions, the precise knowledge of the monetary policy transmission mechanisms in the Central and Eastern Europe countries is extremely important for the correct application of the European Central Bank's monetary policy strategy and for

\footnotetext{
${ }^{1}$ Mihai Niţoi, Ph.D. scholarships of the University of Craiova, Faculty of Economics and Business Administration, through the project POSDRU/6/1.5/S/14 "Increase the attractiveness, quality and efficiency of university doctoral studies by doctoral scholarships".
}

limiting the disadvantages of a unique monetary policy in the countries that will adopt the single currency.

In this paper we intend to study empirically the relative importance of each monetary policy transmission channel, the prices dynamics as well as the way in which each macroeconomic variable response to the different shocks from the economy in Romania.

Our empirical study is based on the estimation of a model based on the structural vector autoregressive methodology, imposing some restrictions on short term. The auto-regressive vector is formed of the following variables: the real industrial production, the real effective exchange rate $^{2}$, the consumer prices index, the M2 monetary aggregate, the exchange rate between the national currency and euro ${ }^{3}$ and the interest rate on the interbank market. The data are monthly, being extracted from the International Monetary Fund's data base (International Financial Statistics) and from the European Central Bank data base (Statistical Data Warehouse)

\footnotetext{
${ }^{2}$ The real effective exchange rate, taken over from the FMI data base and calculated according to the effective exchange rate adjusted to all foreign currencies inflation (of the country and of its commercial partners) is expressed as an index, this index growth indicating a leu's real appreciation against the currencies of the commercial partners of Romania.

${ }^{3}$ The exchange rate is presented as: 1 euro for $x$ units of currency of a country. Consequently when the exchange rate increases (decreases), the respective country's currency depreciates (appreciates).
} 
and they are presented in synthesis in Table no. 1. The period of the study comprises data from 2001 to 2009. Our Structural VAR model comes as a continuation of other similar studies from the Romanian empirical literature of specialty, such as Boţel (2002), Cozmâncă (2008), Aristide (2007). These authors' models were estimated by including different macroeconomic variables in the model and by imposing some restrictions on short term or on long term for surprising as better as possible the economy's evolutions.

Our choice of appealing to an approach based on Structural VAR model is based on the fact that these models remain, irrefutably, a reference in what concerns the shocks. These allow the illustration of the dynamics of a set of variables starting from a restraint number of hypotheses.

However the main limit of the Structural VAR approach when it deals with the monetary shocks is the fact that these models don't take into account the unanticipated part of the monetary shock. Couchrane (1995) illustrated that the absence of the anticipated component can lead to a wrong image of the monetary policy effects.

\section{The elaboration of the Structural VAR model for the Romanian economy}

\subsection{The vector autoregressive methodology}

The formalization of the VAR modelling is presented in multiple sources among which we distinguish Hamilton (1994) and Enders (1995). The following approach (utilized in general form by Favero, 2001) has for unique object the presentation of the Choleski identification, adopted in this model.

We consider the following system with $\mathrm{n}$ variables:

$$
A X_{t}=C(L) X_{t-1}+B v_{t}
$$

where: $A$ is a matrix (nxn) that describes the contemporaneous, structural relations between the variables from the system;
$X_{t}$ is the vector $(\mathrm{n} \times 1)$ of the macroeconomic variables, $\mathrm{C}(\mathrm{L})$ is a matrix lag polynomial; $v_{t}$ is the vector of innovations, $B$ is a matrix ( $n x n)$, which in the great majority of applications (as well as in the present one) is diagonal.

This equation can be rewritten, through pre-multiplication with $A^{-1}$, such as:

$$
X_{t}=A^{-1} C(L) X_{t-1}+u_{t}
$$

where: $u_{t}=A^{-1} B v_{t}$.

The equation (1) describes the structural model, i.e. the economy "real" model. The VAR methodology, by means which will be discussed further on, can analyze the variables response from the system to the structural shocks, $v_{t}$. Unfortunately, the "real" model cannot be observed empirically. The researchers observe only some data series by means of which the coefficients of the equation (2) can be estimated, the so-called model reduced form. As it is clearly observed from the fact that $u_{t}=A^{-1} B v_{t}$, the innovations in a reduced form, $u_{t}$, represent the linear combinations of structural innovations, $v_{t}$. For this reason, before undertaking the innovations analysis, it is necessary to solved the problem of identification, i.e. of "recovering" the structural innovations, $v_{t}$, from the information contained in the reduced form (2).

Mathematically, the structural shocks identification can be done only if some conditions concerning the number of parameters from the system are accomplished. Practically, this problem is solved, commonly, by imposing a priori some zero restrictions (i.e. the imposing of the zero values) to some coefficients of the $A$ and $B$ matrices. Due to the fact that in the case of the $B$ matrix we adopt a common diagonal form in such applications the $A$ matrix restriction remains to be solved. In order to be able to identify the structural innovations, it is necessary to impose at least $n(n-1) / 2$ zero restrictions to the $A$ matrix 
coefficients. If exactly $n(n-1) / 2$ restrictions are imposed, then the system is exactly identified. If more restrictions are imposed, then the system is overidentified.

At this point, an important idea must be underlined. As it was specified above, the A matrix reflects the contemporaneous structural relations, that is the relations of causality or of interdependence between the variables from the model, manifested during the time unit utilized in the analysis (month, trimester, etc.). Consequently, imposing zero-restrictions to the $A$ matrix coefficients is equal to the adoption of some hypotheses on economy's interdependencies. The problem of finding the adequate zero-restrictions in order to identify the structural innovations (also named the decomposition or the orthogonalization of the innovations) was solved in the literature in many ways. The widest practice is the Choleski decomposition.

The Choleski decomposition allows the VAR identification through a perfect orthogonalization of the innovations, by imposing a triangular structure to the innovation matrix, with all the elements on the main diagonal equal to zero. Thus, implicitly a relation of recursive causality between the variables will be established. The shocks identification has as basis the Choleski decomposition, but also the introduction order of the variables in the system. The introduction order of the variables in VAR is determined. The retained criterion in order to introduce the variables for our study is the one of the decreasing exogenity of the variables. This criterion will lead to the introduction of the most exogenous variables in the beginning and of the most endogenous variables in the end. Consequently, the retained order is the following: the industrial production, the real effective exchange rate, the consumer prices index, the M2 monetary aggregate, the leu/euro exchange rate and the interbank interest rate.

\subsection{The Romanian Structural VAR model presentation}

In the standard Structural VAR model, $X_{t}$ is a vector that comprises the following variables: the industrial production $(y)$, the real effective exchange rate (rex), the consumer prices index (p), the M2 monetary aggregate $(m)$, the leu/euro exchange rate (ex), the interest rate on the interbank market (r). The system response to the following structural

shocks: $\varepsilon_{t}^{i p}, \varepsilon_{t}^{r e e r}, \varepsilon_{t}^{c p i}, \varepsilon_{t}^{m 2}, \varepsilon_{t}^{\text {neer }}, \varepsilon_{t}^{i r}$, and $\mathrm{e}_{t}^{i p}, \mathrm{e}_{t}^{r e e r}, \mathrm{e}_{t}^{c p i}, e_{t}^{m 2}, \mathrm{e}_{t}^{n e e r}, \mathrm{e}_{t}^{i r}$ are the innovation terms of the system. All the data are expressed in logarithm (excepting the interest rate), and then the prime difference operator is applied. In this form, the stationarity tests (Augmented Dickey-Fuller) indicate the series stationarity with a degree of trust of over $95 \%$. By applying the prime difference operator we will surprise the way of answer of the variables to the growth rates. All the data are also seasonal adjusted, excepting the exchange rate and the interest rate. All the criteria indicated the Structural VAR model estimation with a lag. The Structural VAR model is stable.

Our system can be schematized as it follows $\left(C_{0}=B^{-1} A_{0}\right)$ :

$$
C_{0}=\left(\begin{array}{cccccc}
c_{11} & 0 & 0 & 0 & 0 & 0 \\
c_{21} & c_{22} & 0 & 0 & 0 & 0 \\
c_{31} & c_{32} & c_{33} & 0 & 0 & 0 \\
c_{41} & c_{42} & c_{43} & c_{44} & 0 & 0 \\
c_{51} & c_{52} & c_{53} & c_{54} & c_{55} & 0 \\
c_{61} & c_{62} & c_{63} & c_{64} & c_{65} & c_{66}
\end{array}\right)
$$


The identification scheme is formed on the relation between the $\left[\begin{array}{cccccc}b_{11} & 0 & 0 & 0 & 0 & 0 \\ 0 & b_{22} & 0 & 0 & 0 & 0 \\ 0 & 0 & b_{33} & 0 & 0 & 0 \\ 0 & 0 & 0 & b_{44} & 0 & 0 \\ 0 & 0 & 0 & 0 & b_{55} & 0 \\ 0 & 0 & 0 & 0 & 0 & b_{66}\end{array}\right]\left[\begin{array}{c}\varepsilon_{t}^{i p} \\ \varepsilon_{t}^{r e e r} \\ \varepsilon_{t}^{c p i} \\ \varepsilon_{t}^{m 2} \\ \varepsilon_{t}^{\text {neer }} \\ \varepsilon_{t}^{i r}\end{array}\right]=$

Taking into account the empirical studies of Blanchard and Quah (1989) and Giannini (1992), our model satisfies the necessary condition of an exact identification of the system, as far as we have to estimate $(n(n+1) / 2)$ parameters. The structure of these matrices leads to 6 theoretical equations that establish a link between the innovation terms and the structural shocks.

The Choleski decomposition shows that certain coefficients of the estimated parameters are from a statistic point of view insignificant. According to Giannini et al. (1995) and Goux, for the amelioration of our identification, we will impose certain additional restrictions on short term on the insignificant parameters.

Making reference to the inferior triangular form of the $A_{0}$ matrix, the real effective exchange rate (the competitiveness of the national goods) should answer to an industrial production shock. However we considered that unlike the production destined to the autochthon consumption which is immediately affected by a shock of the real offer (Blanchard and Quah, 1989), the production destined to the foreign markets isn't influenced by a production unanticipated variation. Consequently, the foreign partners' demand for autochthon goods and services and the real effective exchange rate don't response on short term to an industrial production shock. This is the hypothesis which characterizes an open small economy, such as the economy of structural shocks and the innovation terms $\left(B \varepsilon_{\mathrm{t}}=\mathrm{A}_{0} \mathrm{e}_{\mathrm{t}}\right)$ :

$=\left[\begin{array}{cccccc}1 & 0 & 0 & 0 & 0 & 0 \\ a_{21} & 1 & 0 & 0 & 0 & 0 \\ a_{31} & a_{32} & 1 & 0 & 0 & 0 \\ a_{41} & a_{42} & a_{43} & 1 & 0 & 0 \\ a_{51} & a_{52} & a_{53} & a_{54} & 1 & 0 \\ a_{61} & a_{62} & a_{63} & a_{64} & a_{65} & 1\end{array}\right]\left[\begin{array}{c}e_{t}^{i p} \\ e_{t}^{r e e r} \\ e_{t}^{c p i} \\ e_{t}^{m 2} \\ e_{t}^{\text {neer }} \\ e_{t}^{i r}\end{array}\right]$

Romania. That is why the coefficient of the $a_{21}$ parameter is null.

Following the same approach like Goux (2003), we will suppose that an unanticipated variation of the production will affect only the prices. Consequently, the coefficients of the $a_{41}, a_{51}$ parameters are null $\left(a_{41}=a_{51}=0\right)$, and the real effective exchange rate shock does not affects the monetary variables on short term, so that $a_{42}=0$.

The traditional keynesist theories stipulate that the monetary aggregate affects uniquely only the own equation and the monetary policy equation. This approach implies the nullity of the impact on short term of an unanticipated variation of the monetary aggregate on the real production, on the real effective exchange rate, on the prices and on the exchange rate. The absence of the impact on the first three variables will result from the order of the variables, so that it will be only necessary to specify that $a_{54}=0$.

Sims and Zha (1998) sustain that the monetary policy doesn't answer immediately to the shocks which affect the real production or the prices. The advanced argument is the absence of the statistical dates concerning the prices and the production when the monetary policy decisions are taken. This argument is translated through the nullity of the following coefficients $a_{61}, a_{62}, a_{63}$.

In the literature of specialty, there is a consensus concerning the absence of the monetary policy answer to the exchange rate shocks. Thus it can 
express the absence of the impact on short term of the nominal exchange rate shocks imposing the nullity to the $a_{65}$ parameter. There are also authors such as Sims (1992), Grilli and Roubini (1995), Kim and Roubini (2000) create a polemic in what concerns the relation between an exchange rate shock and the monetary policy. Indirectly, Kim and Roubini (2000) evoke a tridimensional relation between the exchange rate, the prices and the interest rate on short term. They sustain that in the small open economies the monetary authorities pay also attention to the impact of the exchange rate modifications. Consequently, they react instantaneously to the exchange rate shocks through an interest rate increase, on short term.

In these conditions we will suppose that there is an impact of the exchange rate shock on the monetary policy from Romania. As a matter of fact, the estimated coefficient of the $a_{65}$ parameter can be accepted from a statistical point of view.

The Structural VAR identification scheme, after imposing some restrictions on short term, becomes:

$$
\left[\begin{array}{cccccc}
b_{11} & 0 & 0 & 0 & 0 & 0 \\
0 & b_{22} & 0 & 0 & 0 & 0 \\
0 & 0 & b_{33} & 0 & 0 & 0 \\
0 & 0 & 0 & b_{44} & 0 & 0 \\
0 & 0 & 0 & 0 & b_{55} & 0 \\
0 & 0 & 0 & 0 & 0 & b_{66}
\end{array}\right]\left[\begin{array}{c}
\varepsilon_{t}^{i p} \\
\varepsilon_{t}^{\text {reer }} \\
\varepsilon_{t}^{\text {cpi }} \\
\varepsilon_{t}^{m 2} \\
\varepsilon_{t}^{\text {neer }} \\
\varepsilon_{t}^{i r}
\end{array}\right]=\left[\begin{array}{cccccc}
1 & 0 & 0 & 0 & 0 & 0 \\
0 & 1 & 0 & 0 & 0 & 0 \\
a_{31} & 0 & 1 & 0 & 0 & 0 \\
0 & 0 & a_{43} & 1 & 0 & 0 \\
0 & a_{52} & a_{53} & 0 & 1 & 0 \\
0 & 0 & 0 & a_{64} & a_{65} & 1
\end{array}\right]\left[\begin{array}{c}
e_{t}^{i p} \\
e_{t}^{\text {reer }} \\
e_{t}^{c p i} \\
e_{t}^{m 2} \\
e_{t}^{\text {neer }} \\
e_{t}^{i r}
\end{array}\right]
$$

The system is composed of the following six equations:
( $b_{11} \varepsilon_{t}^{i p}=e_{t}^{i p}$
(2) $b_{22} \varepsilon_{t}^{\text {reer }}=e_{t}^{\text {reer }}$
3 $b_{33} \varepsilon_{t}^{c p i}=a_{31} e_{t}^{i p}+e_{t}^{c p i}$
(4) $b_{44} \varepsilon_{t}^{m 2}=a_{43} e_{t}^{c p i}+e_{t}^{m 2}$
(5 $b_{55} \varepsilon_{t}^{\text {neer }}=a_{52} e_{t}^{\text {reer }}+a_{53} e_{t}^{\text {cpi }}+e_{t}^{\text {neer }}$
๑ $b_{66} \varepsilon_{t}^{i r}=a_{64} e_{t}^{m 2}+a_{65} e_{t}^{n e e r}+e_{t}^{i r}$

The first and the second equation illustrate the exogenity of the production shock and of the real exchange rate. The third equation is a function of the prices which proves that the inflation level is determined by the present real production (the principle of the aggregate offer). The variables arrangement in the system indicates the fact that there is no effect from the monetary aggregate, from the exchange rate and from the interest rate on production and on prices. This fact is in accordance with the theoretical hypothesis of the monetary shock's impact absence on the real production and on the prices (Christiano et. al,
1998). The forth equation is a monetary aggregate equation which is explained by the inflation level. The fifth equation is a form of the purchasing power parity as far as the exchange rate is influenced by the prices level and by the real effective exchange rate. The last equation is represented by the monetary authorities' reaction function. The central bank establishes the interest rate after it analyses the evolution of the monetary aggregate and of the prices level, but it doesn't take into account the mutations interfered in the sphere of production and of prices. This fact is enforced because the information concerning the last two variables is available with a lag delay. 


\section{Results and comments}

A positive shock of the industrial production (figure no. 1) will lead firstly to the prices increase, followed then by a period of decrease. A positive variation of production will also determine a national currency appreciation.

Conventionally, in the case of the real exchange rate shock, that is a national currency appreciation, we will assist to the prices decrease. The national currency appreciation will grow the exports price and will reduce the imports price. The decrease of the imported products prices will also lead, in a competitive economy, to the decrease of the autochthon products prices. There from the prices diminution will result. On the other hand this response depends on the existent structure between the exports and the imports. The inflation diminution, as a consequence of a national currency appreciation will be more consistent if the imports are predominant in the national consumption. This argument seems to ply with the economy of Romania (figure no. 1) where the inflation diminished as a result of the leu's appreciation between 2004 and the end of 2007, appreciation that took place on the background of a high consumption oriented towards the imports and the low saving, increasing both the current account deficit and also the external debt. The national currency appreciation in a period in which the current account deficit was substantial can seem ungrounded. It based preponderantly on the capital account liberalization and on the admissions of foreign currency in Romania, admissions that were sustained by the leu's positive interest differential against other currencies, mainly against euro. Along with the financial crisis outbreak, at the end of 2007 in United States, the foreign capital started to be withdrawn from Romania fact that led to significant national currency depreciation. This depreciation would have led to a significant inflation growth if it hadn't been accompanied, due to the economic crisis, by a strong contraction of the production (a negative output gap) and of a current account correction (the consumption that was directed towards imported goods significantly diminished). This mixture of events determined the maintenance of inflation on the descending trend.

The deflationist impact of a positive shock of the real effective exchange rate is reabsorbed through a diminution of the interest rate on short term. This mechanism aligns with the "exchange rate-prices-interest rate" tridimensional relation ${ }^{4}$. Indeed, the unexpected national currency appreciation incites the economic agents to hold an inferior currency stock, which determines an interest rate decrease on short term.

In an economy such as the Romanian economy which adopted the inflation target strategy, the absorption and the competitiveness deterioration (a real effective exchange rate appreciation) through the usual method that is the massive intervention of the monetary authorities on the exchange market through the accumulation reserve fund, is conflictual. This intervention, if it takes place, it will generate a growth of the monetary offer and, implicitly of the inflationist pressures. In this way we can explain the central bank's nonintervention when the leu appreciated against the other currencies. Thus, the central bank will be exposed to the dilemma of practicing a new inflation target and the limitation of the national currency appreciation. Herman (2008) states that the monetary authorities' intervention in order to absorb the national currency appreciation within the inflation target system could be profitable only in the conditions in which the

\footnotetext{
${ }^{4}$ The tridimensional relation "exchange rate- pricesinterest rate" is an extremely important element for the monetary policy behaviour. For this purpose, in order to study the prices sensibility to the exchange rate and to the interest rate, the Central Bank of Canada and of New Zeeland built a monetary conditions index.
} 
economy operates under its potential (negative output gap). Thus an expansionist monetary policy generated by the intervention on the exchange market will favour the realization of the inflation target. This situation isn't also met in Romania, because the output gap was far superior to the economy potential within the period 2004-2008. On the other hand, the adjustment of the national currency appreciation can be realized through an interest rate growth in order to fight against the inflationist pressures generated by the monetary authorities' intervention on the exchange market and the national currency depreciation. However the interest rate growth will cause at its turn a national currency appreciation due to the attraction of the capital waves towards the economy, capital waves attracted by the high interest differential.

Montiel and Ostry (1991) underline the fact that in the context of the free capital flow, the monetary policy task of acting against the inflation is very difficult. The offer of currency cannot be controlled very easy through a restrictive monetary policy (sterilization). As far as the economic agents can obtain foreign liquidities, the direct monetary instruments of enclosing the credit doesn't influence the money supply and thus the inflation. That is why the vocation of an inflation target strategy is the one of anchoring the inflationist anticipations of the population on a level as low as possible.

The positive shock effect of the real exchange rate on the production is disputed. If we take into account the aggregate demand side the decrease of the imports prices and the decrease of the autochthon goods demand, as a result of the national currency appreciation, will lead to a national production collapse. Thus the deterioration of the competitivenessprices of the autochthon goods on international level relation will lead to the exports decrease and will generate a production decrease. On the other hand, if we take into account the aggregate offer side, a national currency appreciation will generate a decrease of the imported intermediate goods prices included in the production factors and thus in the production cost. Consequently, it will increase the labour force demand, but also the production. In Romania (figure 1) the impact of the rate real appreciation on the industrial production seems to be insignificant, thus we can conclude that the effects of the aggregate offer and demand are cancelled. The positive variation of the real exchange rate will also lead to a money supply growth and to a leu's appreciation against euro.

The response of the M2 monetary aggregate to an unexpected inflation growth (figure no. 2) is the one of growing the money supply, unlike the theoretical hypotheses according to which a prices unexpected growth indicates a money supply decrease. However this contradiction was also observed by Kim and Roubini (2000). As an response to an unexpected growth of the inflation the national currency is depreciated against euro, emphasizing thus the inflationist pressures. This relation reflects the incapacity of the exchange rate of absorbing the inflationist effects of the shocks. The positive variation of the money supply (figure no. 2) will also determine an inflation growth and the national currency depreciation. The interest rate growth at a money supply shock indicates a restrictive monetary policy, this measure being an anti-inflationist measure. A positive shock of the nominal exchange rate (figure no. 3 ), concretized in a leu's unexpected depreciation against euro will lead to an inflation growth and to a money supply growth.

A positive aspect that results from the undertaken analysis is represented by the response function of production and of inflation to a positive variation of the interest rate (figure no. 3). 
At the interest rate shock the inflation will decrease significantly, fact that fortifies the interest rate channel and supports the inflation target strategy. We can also observe the same response in the production case. An interest rate growth will also determine a national currency appreciation and a money supply decrease, these functions of response being in concordance with the theoretical hypotheses.

\section{Conclusion}

The present study represents an econometric investigation that wants to surprise the monetary policy dynamics in Romania. For this purpose we appealed to a model based on the auto-regressive structural vector imposing some restrictions on short term. Knowing the functions of response of the main macroeconomic variables to different economic shocks represents an essential step for investigating the Romanian monetary system.

The positive aspect that results from this study is constituted by the lack of "the output puzzles" (the production growth as a result of an interest rate positive deviation) and of "the price puzzles" (the inflation growth as a result of the interest rate positive deviation). This fact can be ascribed to the inflation target strategy which was adopted by Romania.

But the conditions where the integration in the euro zone supposes apart from the prices convergence and the exchange rate convergence the interest rate convergence, the inflation target strategy adopted seems to be rather a flexible inflation target strategy. Taking into account the obtained results by this strategy, in the actual context it seems to be the optimal strategy, but a set of measures for homogenizing the monetary policy and for reducing the gaps against euro zone must be implanted. Only in such context a euro adoption will have benefic effects on the prices dynamics and on other important macroeconomic variables. We also underline the importance and the consistence of the exchange rate channel within the monetary policy, as well as the importance of the monetary aggregates channels in order to explain the evolution of the level of the prices.

Table no. 1 - The data used for the econometric study

\begin{tabular}{|l|c|c|c|c|c|c|}
\hline & $\begin{array}{c}\text { Industrial } \\
\text { production }\end{array}$ & $\begin{array}{c}\text { Real effective } \\
\text { exchange rate }\end{array}$ & $\begin{array}{c}\text { Consumer } \\
\text { prices index }\end{array}$ & $\begin{array}{c}\text { Monetary } \\
\text { aggregate M2 }\end{array}$ & $\begin{array}{c}\text { Ron/Euro } \\
\text { exchange } \\
\text { rate }\end{array}$ & $\begin{array}{c}\text { Interbank } \\
\text { interest rate 3m }\end{array}$ \\
\hline 2002M01 & 79,4182 & 87,68 & 66,541 & 25,993 & 2,83 & 34,800 \\
\hline 2002M02 & 87,744 & 89,11 & 67,301 & 26,709 & 2,80 & 34,200 \\
\hline 2002M03 & 89,185 & 87,26 & 67,551 & 27,533 & 2,87 & 34,500 \\
\hline 2002M04 & 88,945 & 86,98 & 68,921 & 28,607 & 2,93 & 33,600 \\
\hline 2002M05 & 90,386 & 84,87 & 70,201 & 29,063 & 3,07 & 32,600 \\
\hline 2002M06 & 96,311 & 83,66 & 71,041 & 30,091 & 3,19 & 30,600 \\
\hline 2002M07 & 89,746 & 82,45 & 71,401 & 30,348 & 3,27 & 28,600 \\
\hline 2002M08 & 89,346 & 83,70 & 71,981 & 31,485 & 3,23 & 27,100 \\
\hline 2002M09 & 97,111 & 83,70 & 72,421 & 31,733 & 3,25 & 25,800 \\
\hline 2002M10 & 94,309 & 84,62 & 73,611 & 32,493 & 3,26 & 23,900 \\
\hline 2002M11 & 99,673 & 84,81 & 75,481 & 33,458 & 3,36 & 22,400 \\
\hline 2002M12 & 87,264 & 83,92 & 76,611 & 37,371 & 3,43 & 20,500 \\
\hline 2003M01 & 83,421 & 82,24 & 77,601 & 35,572 & 3,55 & 19,700 \\
\hline 2003M02 & 89,346 & 83,28 & 78,231 & 36,740 & 3,54 & 19,000 \\
\hline 2003M03 & 92,548 & 83,35 & 79,071 & 36,945 & 3,58 & 17,600 \\
\hline 2003M04 & 93,749 & 82,60 & 79,921 & 37,859 & 3,66 & 17,800 \\
\hline 2003M05 & 96,791 & 81,46 & 80,311 & 37,910 & 3,76 & 18,200 \\
\hline 2003M06 & 100,073 & 81,17 & 80,981 & 38,850 & 3,81 & 18,200 \\
\hline 2003M07 & 95,430 & 83,58 & 81,961 & 39,088 & 3,71 & 18,200 \\
\hline 2003M08 & 91,747 & 83,26 & 82,171 & 40,740 & 3,72 & 18,700 \\
\hline 2003M09 & 95,670 & 83,04 & 83,931 & 41,447 & 3,79 & 19,200 \\
\hline 2003M10 & 95,670 & 82,92 & 85,221 & 42,377 & 3,88 & 19,700 \\
\hline 2003M11 & 101,915 & 81,60 & 86,441 & 42,565 & 3,99 & 20,300 \\
\hline 2003M12 & 89,506 & 81,78 & 87,452 & 46,074 & 4,06 & 20,800 \\
\hline 2004M01 & 86,944 & 81,63 & 88,422 & 45,222 & 4,11 & 21,100 \\
\hline
\end{tabular}




\begin{tabular}{|c|c|c|c|c|c|c|}
\hline 2004M02 & 94,469 & 83,00 & 88,982 & 45,847 & 4,06 & 21,200 \\
\hline 2004M03 & 94,950 & 83,94 & 89,422 & 48,146 & 4,00 & 21,100 \\
\hline 2004M04 & 97,672 & 82,30 & 89,942 & 48,025 & 4,07 & 21,100 \\
\hline 2004M05 & 101,915 & 83,10 & 90,202 & 49,051 & 4,06 & 21,200 \\
\hline 2004M06 & 99,913 & 82,87 & 90,732 & 50,660 & 4,08 & 20,900 \\
\hline $2004 \mathrm{M} 07$ & 100,634 & 83,43 & 91,892 & 52,511 & 4,10 & 20,300 \\
\hline 2004M08 & 94,469 & 83,70 & 92,392 & 54,839 & 4,09 & 19,600 \\
\hline 2004M09 & 101,194 & 84,20 & 93,262 & 56,740 & 4,11 & 18,900 \\
\hline $2004 \mathrm{M} 10$ & 104,637 & 85,27 & 94,402 & 57,395 & 4,11 & 18,710 \\
\hline $2004 \mathrm{M} 11$ & 103,916 & 88,58 & 95,022 & 56,874 & 3,98 & 18,360 \\
\hline $2004 \mathrm{M} 12$ & 93,989 & 91,70 & 95,562 & 64,462 & 3,87 & 17,640 \\
\hline $2005 \mathrm{M} 01$ & 91,827 & 92,94 & 96,332 & 63,122 & 3,82 & 16,400 \\
\hline 2005M02 & 99,353 & 97,09 & 96,922 & 65,213 & 3,67 & 13,000 \\
\hline 2005M03 & 99,113 & 98,35 & 97,212 & 67,957 & 3,63 & 9,500 \\
\hline 2005M04 & 102,715 & 100,15 & 98,972 & 69,096 & 3,63 & 7,990 \\
\hline 2005M05 & 97,8317 & 100,30 & 99,262 & 71,966 & 3,62 & 7,940 \\
\hline 2005M06 & 99,113 & 98,63 & 99,562 & 74,200 & 3,61 & 7,960 \\
\hline 2005M07 & 97,592 & 101,77 & 100,532 & 74,080 & 3,56 & 7,970 \\
\hline 2005M08 & 93,589 & 103,56 & 100,642 & 76,745 & 3,50 & 7,970 \\
\hline 2005M09 & 103,916 & 103,39 & 101,232 & 80,152 & 3,51 & 8,160 \\
\hline $2005 \mathrm{M} 10$ & 106,478 & 101,62 & 102,102 & 81,098 & 3,60 & 7,070 \\
\hline $2005 \mathrm{M} 11$ & 105,597 & 101,03 & 103,332 & 81,402 & 3,65 & 6,930 \\
\hline $2005 \mathrm{M} 12$ & 102,875 & 101,17 & 103,902 & 86,332 & 3,66 & 6,970 \\
\hline 2006M01 & 96,471 & 102,75 & 104,962 & 85,727 & 3,64 & 7,210 \\
\hline 2006M02 & 103,516 & 105,49 & 105,212 & 85,677 & 3,54 & 7,880 \\
\hline 2006M03 & 103,196 & 106,91 & 105,432 & 87,528 & 3,51 & 8,310 \\
\hline $2006 \mathrm{M} 04$ & 111,442 & 107,78 & 105,882 & 88,034 & 3,49 & 8,390 \\
\hline 2006M05 & 109,280 & 108,44 & 106,522 & 91,747 & 3,51 & 8,420 \\
\hline 2006M06 & 109,680 & 107,56 & 106,692 & 95,054 & 3,55 & 8,570 \\
\hline $2006 \mathrm{M} 07$ & 107,439 & 106,71 & 106,812 & 95,888 & 3,57 & 8,490 \\
\hline 2006M08 & 99,753 & 107,65 & 106,742 & 98,302 & 3,53 & 8,730 \\
\hline 2006M09 & 114,084 & 107,68 & 106,802 & 99,346 & 3,53 & 8,600 \\
\hline $2006 \mathrm{M} 10$ & 113,363 & 107,82 & 107,022 & 100,619 & 3,52 & 8,630 \\
\hline $2006 \mathrm{M} 11$ & 113,203 & 109,58 & 108,192 & 101,940 & 3,50 & 8,670 \\
\hline $2006 \mathrm{M} 12$ & 116,165 & 113,06 & 108,992 & 111,711 & 3,41 & 8,230 \\
\hline 2007M01 & 101,034 & 113,37 & 109,232 & 106,255 & 3,39 & 8,030 \\
\hline 2007M02 & 106,878 & 113,70 & 109,282 & 109,241 & 3,38 & 7,890 \\
\hline 2007M03 & 117,766 & 114,25 & 109,372 & 112,419 & 3,37 & 8,250 \\
\hline 2007M04 & 105,597 & 115,88 & 109,942 & 112,944 & 3,33 & 8,040 \\
\hline 2007M05 & 120,488 & 118,25 & 110,642 & 112,664 & 3,28 & 8,980 \\
\hline 2007M06 & 116,485 & 120,16 & 110,822 & 116,127 & 3,22 & 7,580 \\
\hline $2007 \mathrm{M} 07$ & 115,445 & 124,06 & 111,152 & 119,934 & 3,13 & 6,490 \\
\hline 2007M08 & 109,680 & 121,40 & 112,112 & 124,293 & 3,22 & 6,460 \\
\hline 2007M09 & 118,727 & 118,08 & 113,332 & 126,508 & 3,35 & 6,770 \\
\hline $2007 \mathrm{M} 10$ & 121,929 & 118,72 & 114,432 & 128,738 & 3,35 & 7,090 \\
\hline 2007M11 & 119,207 & 115,50 & 115,502 & 136,109 & 3,47 & 7,440 \\
\hline 2007M12 & 105,197 & 113,82 & 116,252 & 147,918 & 3,54 & 7,600 \\
\hline $2008 \mathrm{M} 01$ & 107,707 & 109,71 & 117,242 & 147,352 & 3,69 & 7,960 \\
\hline 2008M02 & 116,276 & 111,58 & 118,072 & 149,685 & 3,66 & 9,350 \\
\hline 2008M03 & 124,844 & 110,87 & 118,872 & 151,988 & 3,72 & 9,440 \\
\hline $2008 \mathrm{M} 04$ & 112,682 & 114,42 & 119,502 & 157,044 & 3,64 & 10,340 \\
\hline 2008M05 & 123,554 & 113,43 & 120,082 & 157,568 & 3,66 & 10,680 \\
\hline 2008M06 & 121,343 & 113,31 & 120,422 & 161,463 & 3,66 & 10,400 \\
\hline $2008 \mathrm{M} 07$ & 120,053 & 116,12 & 121,272 & 161,221 & 3,58 & 10,750 \\
\hline 2008M08 & 102,271 & 116,72 & 121,172 & 162,280 & 3,53 & 12,070 \\
\hline 2008M09 & 120,790 & 113,57 & 121,652 & 166,013 & 3,62 & 11,860 \\
\hline $2008 \mathrm{M} 10$ & 124,291 & 110,72 & 122,952 & 162,148 & 3,75 & 15,720 \\
\hline $2008 \mathrm{M} 11$ & 110,195 & 110,56 & 123,362 & 164,370 & 3,78 & 15,040 \\
\hline 2008M12 & 90,570 & 108,09 & 123,662 & 173,736 & 3,92 & 12,800 \\
\hline 2009M01 & 92,873 & 101,76 & 125,202 & 175,771 & 4,24 & 13,070 \\
\hline 2009M02 & 100,152 & 101,31 & 126,232 & 175,838 & 4,29 & 15,140 \\
\hline 2009M03 & 109,642 & 102,68 & 126,862 & 174,882 & 4,28 & 14,040 \\
\hline $2009 \mathrm{M04}$ & 103,561 & 104,69 & 127,212 & 175,808 & 4,20 & 12,290 \\
\hline 2009M05 & 113,327 & 105,26 & 127,222 & 176,175 & 4,17 & 11,020 \\
\hline 2009M06 & 113,604 & 104,53 & 127,472 & 179,482 & 4,21 & 10,050 \\
\hline 2009M07 & 112,406 & 104,18 & 127,392 & 180,373 & 4,22 & 9,240 \\
\hline 2009M08 & 99,138 & 103,53 & 127,152 & 182,785 & 4,22 & 8,830 \\
\hline 2009M09 & 115,815 & 103,87 & 127,642 & 182,527 & 4,24 & 9,000 \\
\hline 2009M10 & 119,777 & 103,39 & 128,202 & 182,564 & 4,29 & 9,560 \\
\hline
\end{tabular}




\section{Figure no. 1 - The responses of variables to industrial production shock (Shock1) and to real effective exchange rate shock (Shock2)}

Response to Structural One S.D. Innovations \pm 2 S.E.

Response of DLIP_SA to Shock1

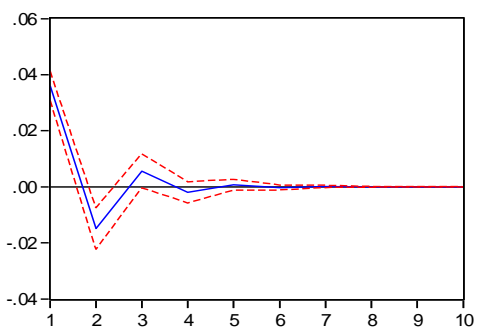

Response of DLCPI_SA to Shock1

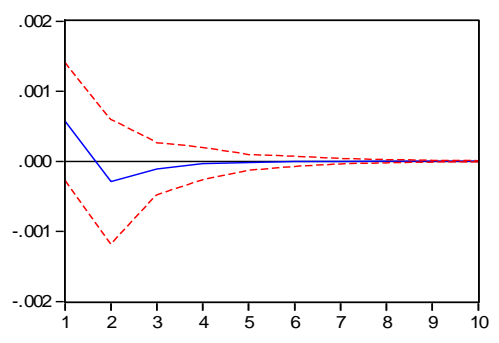

Response of DLNEER to Shock

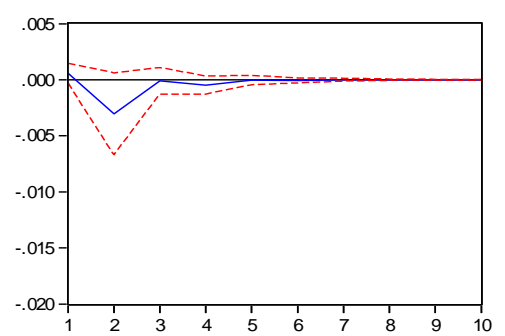

Response of DLIP_SA to Shock2
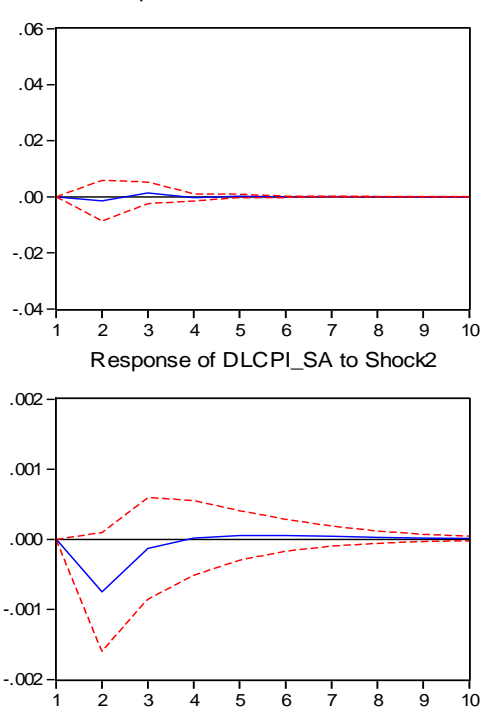

Response of DLNEER to Shock2

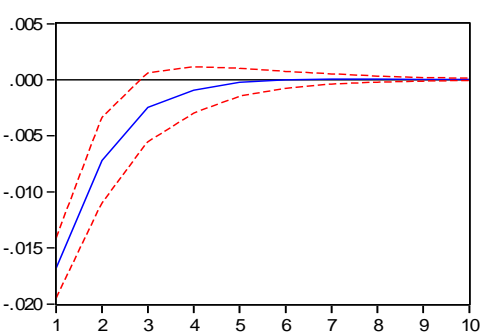

Response of DLREER to Shock1
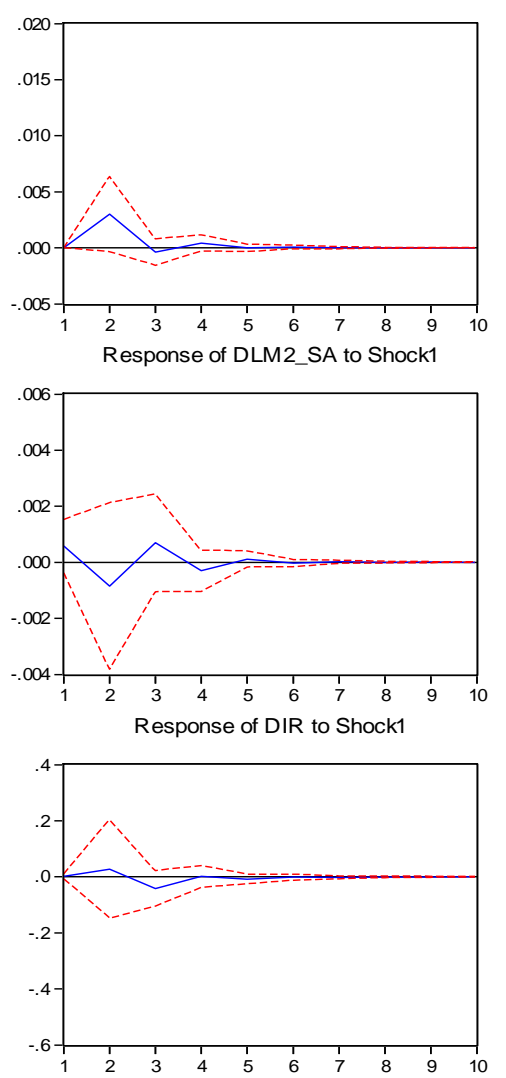

Response of DLREER to Shock2
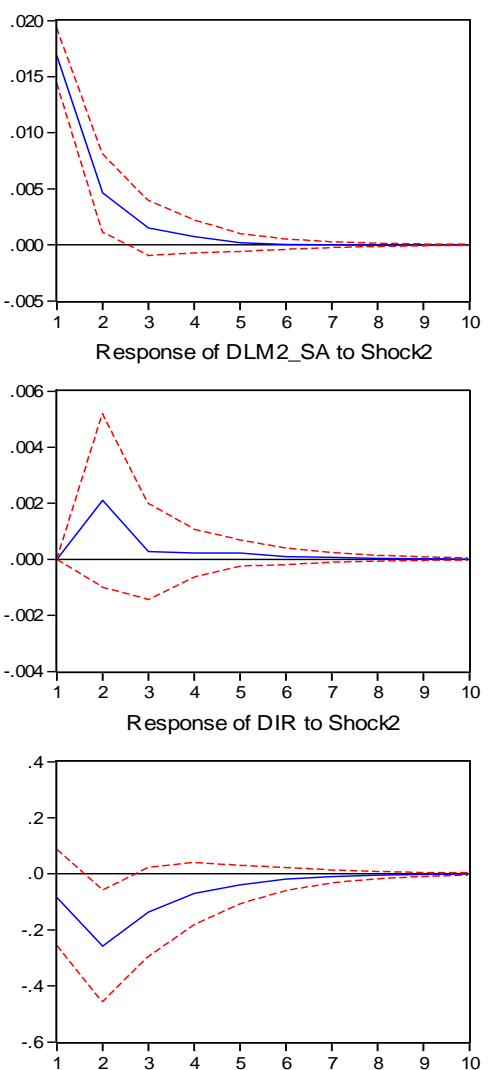


\section{Figure no. 2 - The responses of variables to inflation shock (Shock3) and to aggregate monetary shock (Shock4)}

Response to Structural One S.D. Innovations \pm 2 S.E.

Response of DLIP_SA to Shock3

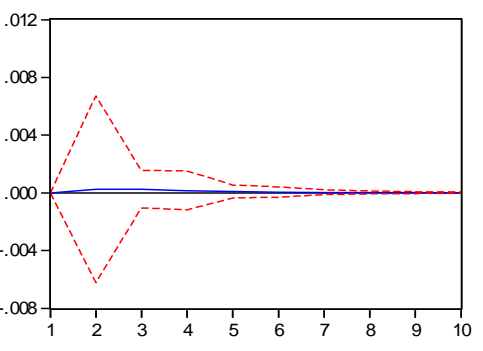

Response of DLCPISA to Shock3
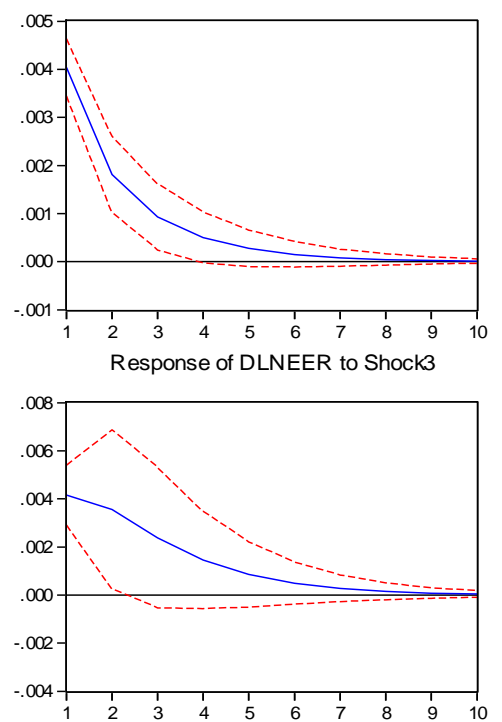

Response of DLIP_SA to Shock4

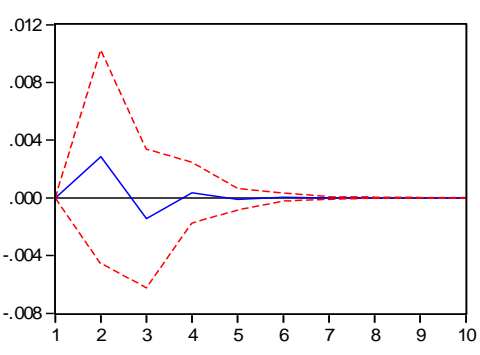

Response of DLCPISA to Shock4

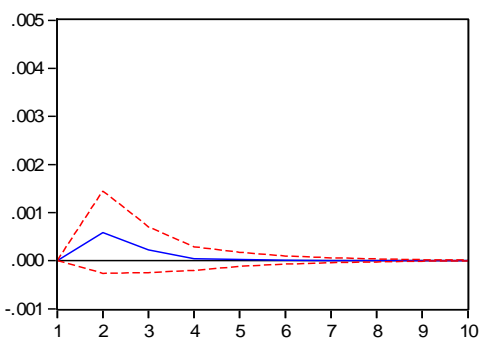

Response of DLNEER to Shock4

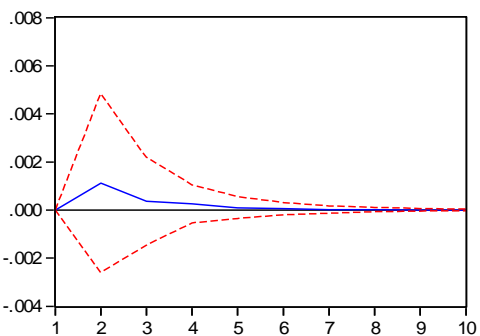

Response of DLREER to Shock3

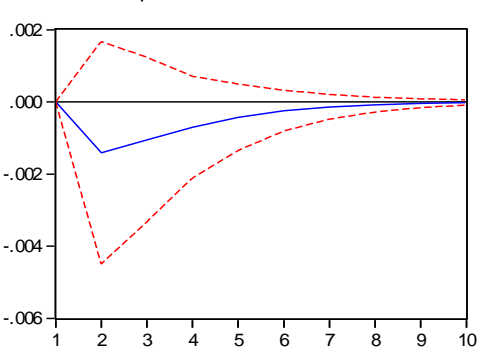

Response of DLM2 SA to Shock3

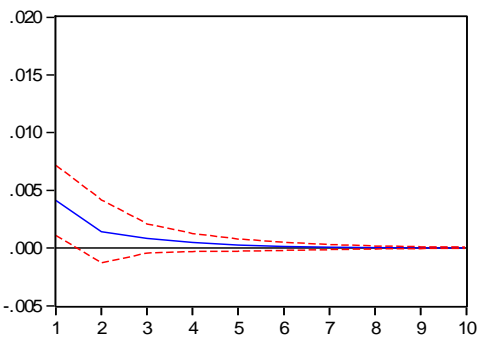

Response of DIR to Shock3

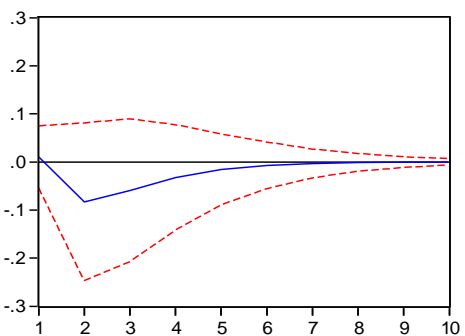

Response of DLREER to Shock4

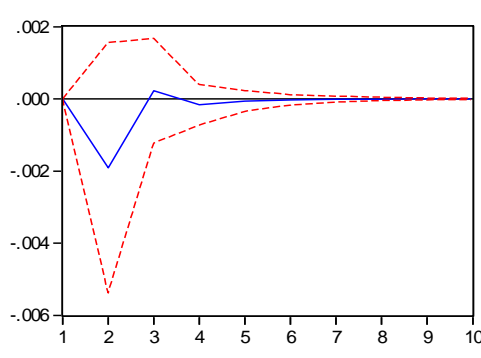

Response of DLM2 SA to Shock4

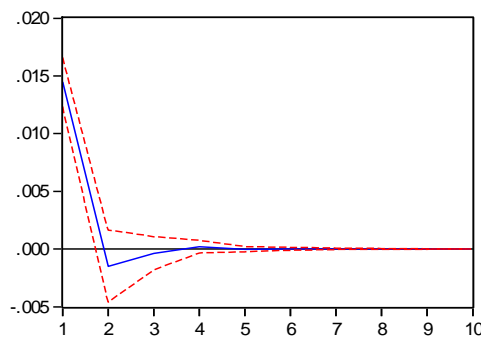

Response of DIR to Shock4

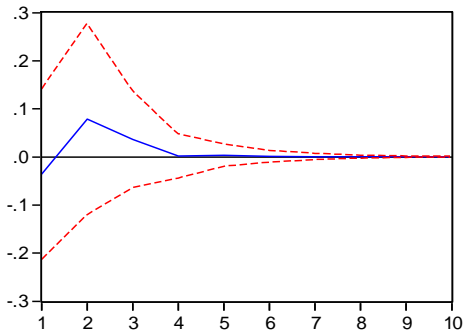


Figure no. 3 - The responses of variables to exchange rate shock (Shock5) and to interest rate shock (Shock6)

Response to Structural One S.D. Innovations \pm 2 S.E.

Response of DLIP SA to Shock5

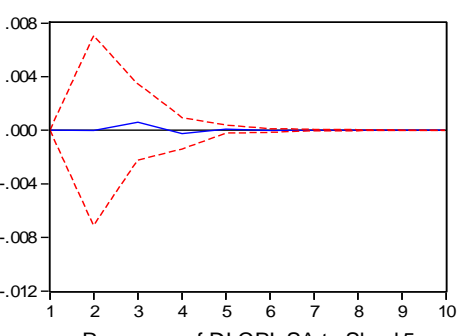

Response of DLCPI SA to Shock5

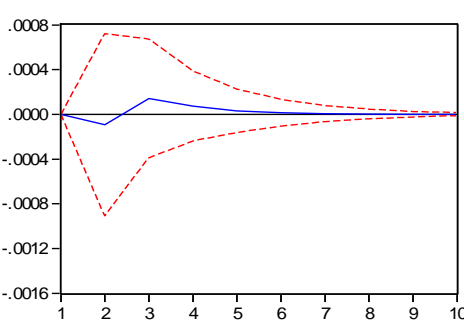

Response of DLNEER to Shock5

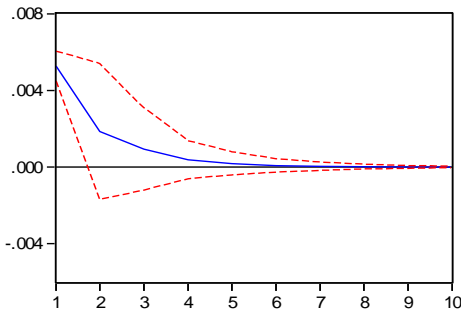

Response of DLIP_SA to Shock6

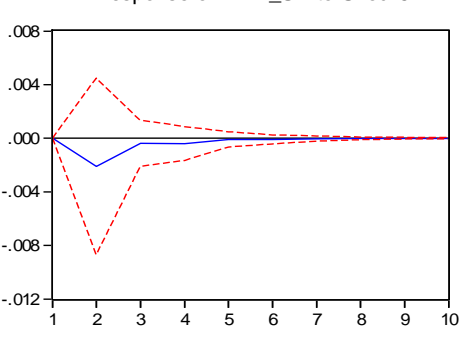

Response of DLCPI SA to Shock6

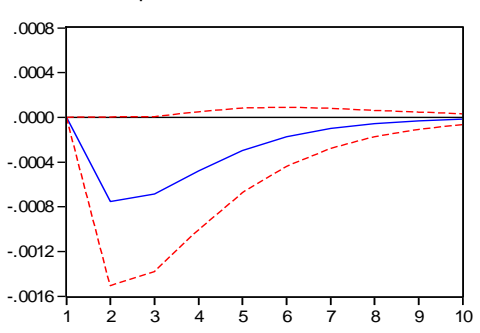

Response of DLNEER to Shock6

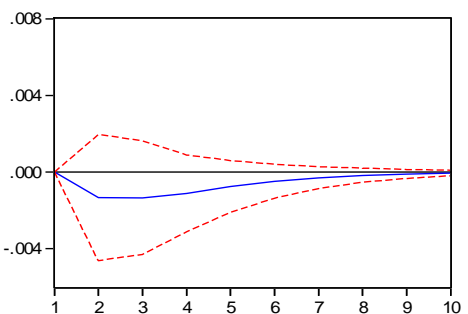

Response of DLREER to Shock5

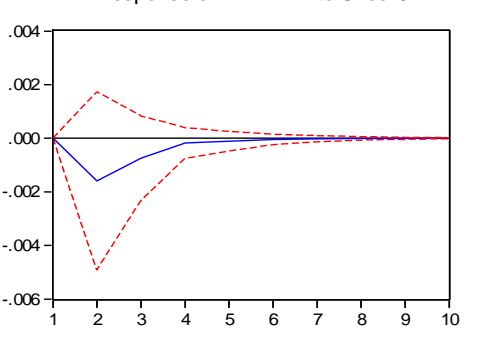

Response of DLM

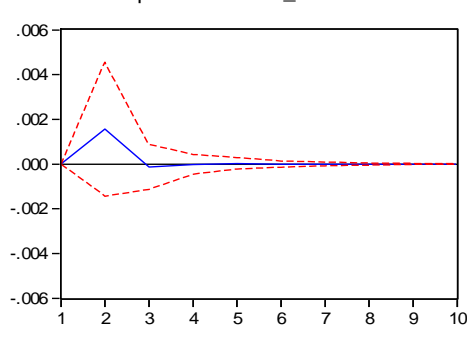

Response of DIR to Shock 5

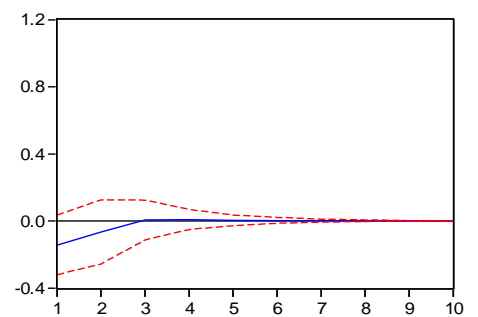

Response of DLREER to Shock6

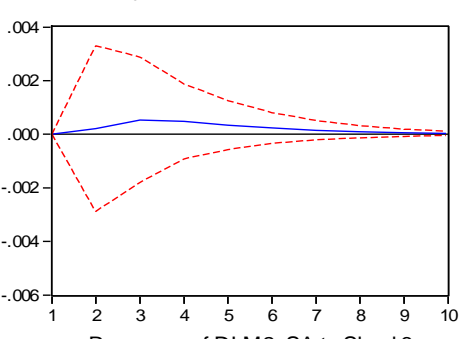

Response of DLM2 SA to Shock6

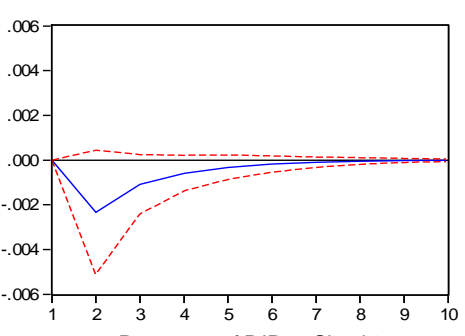

Response of DIR to Shock6

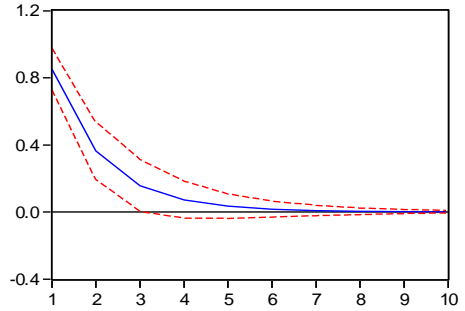




\section{REFERENCES}

Aristide, O., 2007

Benassy-Quéré, A., A. Lahreche-Revil (2001)

Blanchard, O. J. et Quah, D., 1989

Boţel, C., 2002

Couchrane, J.H., 1995

Cozmâncă, B., 2008

Christiano, J.L., Eichenbaum, M. et Evans, C.L., 1998 Enders, W., 1995

Favero, C.A., 2001 Giannini, C., 1992

Giannini, C., Lanzarotti, A. et Seghelini, M., 1995 Goux, J.F., 2003

Grilli, V. et Roubini, N., 1995

Hamilton, J.D., 1994

Herman, K., 2008

$\mathrm{Kim}, \mathrm{S}$. et Roubini, N., 2000

Mishkin, F.S., 2000

Montiel, P. et Ostry, J., 1991

Sims, C.A. et Zha, T., 1998
"Impactul salariilor din economie asupra inflaţiei şi deficitului comercial", Caiet de Studii nr. 24, Banca Naţională a României;

"L'Elargissement de la Zone Euro", Cepii (ed.), L'Economie mondiale 2002, Paris: La Découverte;

"The Dynamic Effects of Aggregate Demand and Supply Disturbances", American Economic Review, vol.79, no.4;

"The Dynamic Effects of Aggregate Demand and Supply Disturbances", American Economic Review, vol.79, no.4;

"Identifying the Output Effects of Monetary Policy", NBER Working Paper no.5154, National Bureau of Economic Research, Cambridge, Massachusetts;

"Modele pentru fundamentarea politicilor monetare valutare", Editura Economică, Bucureşti;

"Monetary Policy Shocks: What Have We Learned and to What End?", NBER Working Paper no.6400, National Bureau of Economic Research, Cambridge, Massachusetts;

"Applied econometric time series", John Wiley \& Sons, Inc;

"Applied macroeconometrics", Oxford University Press, Oxford;

"Topics in Structural VAR Econometrics", Lecture Notes in Economics and Mathematical Systems, Springer-Verlag, Heidelberg;

"A Traditional Interpretation of Macroeconomic Fluctuations: The Case of Italy", European Journal of Political Economy, vol.11, p.131155;

"Conditions monétaires et activité économique dans la zone euro", Document de travail no.03-06, Groupe d'Analyse et de Théorie Économique, CNRS;

"Liquidity and Exchange Rates: Puzzling Evidence from the G-7 Countries", Working Paper, Yale University;

"Time Series Analysis", Princeton University Press, Princeton;

"Is Central Bank Intervention Effective Under Inflation Targeting Regimes? The Case of Colombia", Working Paper no.WP/08/88. IMF, Washington, D.C.;

"Exchange Rate Anomalies in the Industrial Countries: A Solution with a Structural VAR Approach", Journal of Monetary Economics, no.45, p.561-586;

"From Monetary Targeting to Inflation Targeting: Lessons from the Industrialized Countries", Paper presented in the conference of The Bank of Mexico, Stabilization and Monetary Policy: The International Experience. Mexico City, November 2000;

"Macroeconomic Implications of Real Exchange Rate Targeting in Developing Countries", Staff Paper Vol.39, Mars, p.872-900. IMF, Washington, D.C.;

“Does Monetary Policy Generate Recession?", Federal Reserve Bank of Atlanta, Working Paper no.98-12. 